\title{
Professional Competency Differences among High School Teachers in Indonesia
}

\author{
M. Nur Mustafa ${ }^{1}$ \\ ${ }^{1}$ Faculty of Education, University of Riau, Indonesia \\ Correspondence: M. Nur Mustafa, Faculty of Education, University of Riau, Indonesia. E-mail: \\ em_nur1388@yahoo.com
}

Received: July 15, 2013 Accepted: August 6, 2013 Online Published: August 27, 2013

doi:10.5539/ies.v6n9p83 URL: http://dx.doi.org/10.5539/ies.v6n9p83

\begin{abstract}
This study aims to evaluate the levels of professional competency among high school teachers as well as to identify the differnces based on gender and work experience, as the teachers' professional competency level is of paramount importance in quality of teaching and learning and students' achievements. The study sample involved 327 teachers from various fields randomly selected from 12 schools in Pekanbaru, Indonaisia. The study used test with 33 questions to measure the teachers' professional competency. Overall results show that the level of professional competencies is generally at an average level. The result shows that there is significant difference between female and male teachers in terms of mastery of professional competency. In addition, the data shows that there is significant difference between more experienced and less experienced teachers regarding mastery of professional competency. The implication is that the program, run by schools or ministery of education, to implement to upgrade the professional competency of teachers should consider the teachers' backgrounds to make sure its effectiveness.
\end{abstract}

Keywords: professional competencies, teachers, gender, working experience

\section{Introduction}

Teaching profession requires specific knowledge and skills (Abdul Razaq et al., 2013). Therefore, teacher education curriculum is designed to ensure that teachers are competent in content knowledge and pedagogical skills. By mastering these two main elements, teachers are able to face challenges in school. Norlander (2009) suggests that effective teacher is a person who is able to carry out his duties and responsibilities successfully. Past studies showed that effective teachers must have broad knowledge and pedagogical skills to promote appropriate behaviour (Awang, Jindal-Snape, \& Barber, 2013). Public assumes that being a teacher is an easy job. Indeed, trainee teachers also assume that the duties of a teacher are easy, manageable and could be carried out successfully. Due to this paradigm, most trainee teachers are not serious in gaining knowledge during teaching training. As a result, it brings adverse effects to the teaching profession. In reality, being a teacher is not an easy task. Teachers have to fulfil parents' expectations and they need to ensure that children are well-educated. Therefore, all teachers have to improve their teaching skills and content knowledge. The following elements and domains are supposed to be fulfilled by all teachers: personality, intellectual, emotion, inter-personal skills, intra-personal skills and creativity in teaching.

Teaching profession is a professional designation which requires resilience, competitiveness and good leadership skills. These come from individual talent and abilities. Good teachers are those who are expert in teaching subject content and able to manage personel, teaching aids and classroom effectively. Teachers who have undergone training should possess the competencies based on the theoretical knowledge, practical training and softskills.

Walker, Jeffes, Hart, Lord, and Kinder, (2011) have discovered that teaching implementation depends on the involvement and versatility of teachers in establishing an interesting and effective learning environment. How well a teacher adopts all the knowledge and involvement could be seen in the implementation process. According to Kearsley (1997), teachers' dedication in carrying out the activities to inculcate teaching content is greatly influenced by the mastery of teaching aids and in making changes in students' behaviour. Hence, teachers have to be sensitive towards the latest development in education world today. Teachers have to be positive and strive to improve the standard of education so that the quality of teaching and learning is improved. 
According to Sutadipura (1985), constant thinking and acting which is consistent and continuous could develop a competent person who possess knowledge, skills, values and basic attitudes towards accomplishing something. Professional career requires thinking out of the box and away from mundane routines. This is what it means by professionalism via effort and training. Competencies will influence a person's work performance in carrying out his duties as a social agent to the students. 14th rule of the Republic of Indonesia in 2005 defines professional competencies as a set of knowledge, keterampilan and behavior which have to be possessed, observed and mastered professionally. Teachers are educational managers and leaders in a classroom. Therefore teachers who are competent would be able to carry out his teaching successfully, making full use of resources and materialise teaching process successfully.

Teachers are expected to work systematically, consistently and creatively (Arifin 2002). According to Edmond, N., \& Hayler, M. (2013) professional competencies are crucial skills which determine the success of a teacher in carrying his duties as professional. The following questions provide general guidelines to explore teachers' competencies:

- What are the standards that have to be achieved by teachers to perform effective teaching?

- What are the skills required to teach?

- What are the questions asked to test students' knowledge?

Teachers' competencies are aligned with the ability to manage information, framing duty solving and active communication with students. Teachers also have to possess the knowledge about subject curriculum and syllabus through accurate testing procedures. In other words, teachers should be able to integrate the use of technology compatible with the standard technology for undergrads in developing curriculum. Teachers have to know how to make use of technology and cognitive thinking process which is complex. Teachers should also be able to know how students learn and understand the difficulties faced by the students. According to Soedijarto (1989), professional teachers have to master:

- knowledge discipline as teaching resources,

- teaching content that is going to be delivered,

- knowledge about undergrads' characteristics,

- knowledge about the philosophy and aims of education,

- mastery of teaching methods and models of teaching,

- mastery of technological principles of learning, and

- ability to lead and direct learning environment.

In an Indonesian context, professional competencies refer to the mastery of education in depth which enables teachers to guide students and manage teaching activities [National Education Standards, phase 28, line 3, clause (c)]. Loughran, Berry, and Mulhall (Eds.) (2012) agree that competent teachers would make the effort to relate teaching content with students' background knowledge and provide effective learning experience through assignments, exercises and homework which are of high quality. Biggs, and Tang (2011) realize that there is a relationship between the steps taken by teachers to simplify and master teaching content with their competencies.

\section{Statement of the Problem}

The current study was influenced by past studies on professionalism in teaching profession where it was found that most teachers have a lack of professionalism. Three contributing factors identified to the low level of teachers' professionalism are: (1) many teachers who do not fully carry out their profession; (2) low level of loyalty towards the norms and teaching ethics; and (3) unsatisfactory acknowledgement of teachers towards educational knowledge in implementing the policies to the involved parties (Biggs, and Tang, 2011). Past studies also revealed that teachers' integrity and accountability are often questionable. Most issues raised about teachers are regarding the school milieu and teachers' competency in managing classroom and delivering lesson. A teacher should be accountable to his duties and therefore will work hard and show sense of responsibilities and subsequently will be proud of their job (Cruickshank et al., 2006). There is no excuse for a teacher especially those of the higher ranking $(\mathrm{PN})$ to be less proud of their duties and responsibilities. This is because they take a vow towards their work responsibilities before they even start working, like any other government officers (Lichtenberger, 2013; Mulyasa 2005).

The effort to improve teachers' quality actually does not stop when they are assigned to their workplace. Instead, it continues for the rest of their teaching profession. It is observed that the quality of work declines as they serve 
longer in the service. Empirical research on teachers' burnout caried out by Morrison et al. (2005) revealed that the non academic routines of teachers reduce their mood to keep on learning and improve their professionalism that they refuse to change due to high pressure at work, high workload and role conflicts. Burnout causes emotional exhaustion, physical exhaustion, attitudinal exhaustion and low feeling of accomplishment. Consequently this affects the quality of their dedication and treatment towards their students. Therefore efforts and measures have to be taken to improve the ability and quality of a teacher. According to Jamal (2009), teachers' readiness change and the optimum use of their professional skills is still limited and not developing and making full use of their professional skills is still limited that it does not improve their perseverance towards the challenges and changes that are happening.

Sadirman (2004) discovered that there are students who are not happy and scared of teachers. Some teachers always scold their students during teaching and learning activities. Some teachers have a lack of punctuality. Some of them have been teaching the same topics repeatedly. This discourages students to be involved in lesson activities.

\section{Past Studies on Teachers Competency}

Competency is the capacity to carry out teaching and learning process succsesfully (Mulyasa 2005). Capacity is also shown when an individual is successful in learning how something complex and abstract is done. According to Indriyanto (2001), competency is the potential skill and expertise in conducting one's roles. The basic competencies of a teacher consist of these components: time management, focus, feedback, forecast, decision making, and transfer of knowledge and culture.

The research carried out by Widyoko (2005) on teachers' competency shows that most teachers have an average level of competency. That study demonstrated that teaching experience has a positive impact on teachers' compentency level. In addition to this factor, abilities to integrate modern technology and manage classroom efectively were found to be problems for some teachers (M. Nur, 2013).

The international scenario of competency in a more general organisation which reveals a similar situation regarding the organisational climate towards profesional competencies. Gorman et al. (1997) introduced a competency model based on the study on outstanding skills and leadership qualities. Thst study utilsed qualitative research design using individual interviews. Each individual was interviewed and results suggest the importance of emotional intelligence to improve competencies in handling organisational climate. Important elements identified including interpersonal skills, initiative, possessing a vision, cognitive abilities, technical skills, and high level of IQ. Five emotional intelligence investigated in that study were self-awareness, self-discipline, high level of motivation, high level of empathy and inter-personal skills.

Pillay (2005) has carried out a study on the relationship between burnout and teachers' competencies in Queensland. That study reveals that teachers' workload has a high correlation with burnout tendencies among teachers. It has negatively affected teachers' working competencies. The research discovers that working practices and working environment such as competitions, working nature transformation and technology could bring impact on the wellness and competencies of teachers.

According to Davies (2000), the creative process of learning is crucial for a teacher. Teachers have to be creative role models for the students. In addition, Baghart and Trull (1973) who have carried out the research on the competency level of creative teachers have proposed several measures that could be adopted by teachers, namely: the ability to accomodate to students' learning style, creating a fun learning environment, inculcate living skills and versality in the students, reduce all barriers and limitations in learning activities

Learning Implementation Plan (RPP) that was introduced in Indonesia posits that pegagogical competency is the ability of teachers to carry out learning experience that includes the understanding of education policies, the understanding of students, curriculum development, learning plans, learning implementation, benefits of learning outcomes, learning outcome evaluation, the realisation of students' potential

Gillies, Ashman, Battistich, Watson, Terwel, Schnackenberg, and Abrami (2013) emphasise that the most important things to be considered in teaching practise are regarding the learning outcomes and questioning techniques used. These will lead to effective learning and improve learning readiness and cognitive ability among students. Everything begins with the understanding of the simplest to the most complex ones. Good teaching practice will provide students with the education in critically thinking involving the process of recalling information, handling information, analyzing, making analogy ( to compare and contrast), making interpretations, syntesizing and evaluating. 
According to the criteria set forth by UNESCO, quality education is the combination between professional teachers with integrity and competency. Thiessen (2012) stressed that the quality of teacher should be given priority in the effort to develop effective teaching pattern. The quality of teachers is measured through personal competency, work performance, motivation, effort and changes in students' behaviour.

Walker, et al. (2011) suggests that teachers need to improve their delivery quality in order to meet the professional standards. These include the working style, teaching practice, and the use of interactive approach in communication. Serving quality is the product produced by the workers within a time frame which includes high socialization ability among workers to be able to share working qualities. Teachers are able to avoid the decline of work performance due to burnout by sharing their workloads (Hinshaw, Richter, and Kramer, 2010).

Mulyasa (2006), Arikunto (2004) and Sukandar (2003) proposed several criteria for competent teachers. They have initiated specific tests in their studies which then were utilised in the current study. These tests were adapted and modified to fulfil the current research objectives. The validation of the items in the test was referred to educational experts in Indonesia. The pilot study was then carried out where Cronbach Alpha scores indicated that the items were appropriate to be used.

\section{Purpose of the Study}

The current study aims to evaluate the mastery of professional competency among high school teachers as well as to identify the differnces based on gender and work experience in Pekanbaru, Indonaisia. Regarding the mastery of professional competency, the purpose of the study is to identify the level of profesional competency among teachers, focusing on mastery in education foundation, vision, mission and educational objectives, national educational standards, curriculum development, classroom management, usage of media and educational resources. Furtermore, the differnces concerning the mastery in professional competency among teaches, are identified based on gender and work exprience.

\section{Methodology}

The current study employed test to evaluate the mastery of profesional competency among teachers in Riau, in Indonaisia. The test of mastery of profesional competency contains 33 items which were divided into 6 constructs to evaluate mastery in education foundation ( 6 items), vision, mission and educational objectives ( 6 items), national educational standards (6 items), curriculum development moves (6 items), classroom management(5 items), and the ability to use media and educational resources (4 items). Sample of this study was selected using simple random technique involving 327 teachers (132 males and 195 females) from various fields in 12 secondary schools.

To validate the fcace and content validity of the test questions, we refered to the professional and expersts, and also ministery of education in Indonaisia to assure the questions are understandable can measure the professional competency of teachers. Pilot test was conducted in one secondary school involving 50 teachers. All the items in the competency level and professional competency test show high validity and reliability in which the value of Cronbach Alpha is 0.82 . This indicates that all items are acceptable and appropriate to be used. Data analalysis was performed using descriptive and inferential statistics including the score mean, percentage, ANOVA and MANOVA. To measure the competency level and professional competency among teachers, this formula was used:

$$
\text { Total Score }=\quad \frac{\text { Obtained Score }}{\text { Raw Score }} \times 100
$$

Teachers' professional competency level is measured based on the five level mean scores. Table 1 shows the interpretation of the test scores.

Table 1. Interpretation of the Profesional Competency Test Scores

\begin{tabular}{ll}
\hline Score & Interpretation \\
\hline $0-54$ & Not competent \\
$55-64$ & Less competent \\
$65-79$ & Quite competent \\
$80-89$ & Competent \\
$90-100$ & Very competent \\
\hline
\end{tabular}




\section{Results and Discussions}

Overall results indicate that most teachers are quite competent (Table 1). Detailed analyses revealed that teachers are competent in two aspects that are the mastery of education foundation and the mastery of vision, mission and educational objectives.

Table 2. Mastery in professional competency level among teachers

\begin{tabular}{llll}
\hline $\begin{array}{l}\text { Professional Competency Aspects } \\
(\mathrm{n}=327)\end{array}$ & Mean & $S D$ & Interpretation \\
\hline Education foundation & 83.49 & 15.12 & Competent \\
Vision, mission and educational objectives & 81.65 & 15.78 & Competent \\
National educational standards & 71.25 & 26.73 & Quite Competent \\
Curriculum development & 65.32 & 16.92 & Quite Competent \\
Classroom management & 60.30 & 20.09 & Less Competent \\
Usage of media and educational resources & 58.10 & 22.58 & Less Competent \\
\hline Average Mean Score & 70.02 & 9.46 & Quite Competent \\
\hline
\end{tabular}

Level of significance $<0.005$

The level of professional competency among teachers generally is satisfactory. This shows that the serving quality among them is at average level. This reveals that the teachers are mastering the professional competency. Results also indicate that teachers are less competent in classroom management and the use of media and educational resources. Past study suggests that a teacher has to be accountable of his duties which will encourage them to work hard and show high sense of responsibilities that they would be proud of their career (Cruickshank et al., 2006). The result of this study is consistent with the findings of a study by Mustafa M. Nur (2012) in which she reported that the teachers' work performances also were not satisfactory. Recent research carried out by by ministery of education in Riau Indonaisia (2006) revealed that $45 \%$ of the teachers are still teaching using lecturing method. The use of modern technology was limited. Hence, it contributes to less productive learning. Teachers have to take various efforts to improve qualities including all the competency elements mentioned. Detailed analyses were carried out to seek differences and commonalities between genders.

\section{Gender and Teachers' Profesional Competency}

Results show that the professional competency among female teachers is higher than male teachers. Accordingly, Table 3 shows that there are significant differences between genders with regard to the aspects of mastery of education foundation (0.028), mastery of vision, mission and education $(0.000)$, understanding and mastery of national education standards (0.021), mastering and developing curriculum (0.010); however, in terms of the mastery of classroom managemen and ability to use media and education resources there is no significant difference $(0.735)$ and $(0.637)$ respectively based on gender.

These results are parallel with previous researches such as by Anderson (1990) and Bakalis (2003) which state that female teachers are more committed in the teaching profession compared to male teachers. Results from this study is also consistent with the research results obtained by Widoyoko (2005) who found that female teachers' professional competency level is higher than that of the male teachers. However, the competency in classroom management does not show any differences between male and female teachers in the research carried out by Shullman (1990). Teachers only focus on the delivery of teaching in the classroom towards academic improvement which consequetly does not show obvious differences (Marks 1991). 
Table 3. Mastery of professional competency level, by gender

\begin{tabular}{|c|c|c|c|c|c|c|c|c|c|}
\hline Aspects & Gender & $\mathrm{n}$ & Mean & SD & $\begin{array}{l}\text { Type } \\
\text { Total } \\
\text { square }\end{array}$ & $\mathrm{df}$ & $\begin{array}{l}\text { Mean } \\
\text { Square }\end{array}$ & $\mathrm{F}$ & $\mathrm{p}$ \\
\hline \multirow{2}{*}{$\begin{array}{l}\text { Education } \\
\text { Foundation }\end{array}$} & Male & 132 & 81.25 & 17.02 & 110.94 & 1 & 110.9 & 4.90 & 0.028 \\
\hline & Female & 195 & 85.00 & 13.53 & & & & & \\
\hline \multirow{2}{*}{$\begin{array}{l}\text { vision, mission and } \\
\text { education objectives }\end{array}$} & Male & 132 & 75.76 & 15.73 & 769.14 & 1 & 7689.1 & 34.0 & 0.000 \\
\hline & Female & 195 & 85.64 & 14.54 & & & & & \\
\hline \multirow{2}{*}{$\begin{array}{l}\text { Understanding and } \\
\text { national education } \\
\text { standards }\end{array}$} & Male & 132 & 67.12 & 25.70 & 379.38 & 1 & 378.3 & 5.36 & 0.021 \\
\hline & Female & 195 & 74.05 & 27.12 & & & & & \\
\hline \multirow{2}{*}{$\begin{array}{l}\text { developing } \\
\text { curriculum }\end{array}$} & Male & 132 & 62.39 & 19.14 & 191.45 & 1 & 190.4 & 6.78 & 0.010 \\
\hline & Female & 195 & 67.31 & 14.97 & & & & & \\
\hline \multirow{2}{*}{$\begin{array}{l}\text { classroom } \\
\text { management }\end{array}$} & Male & 132 & 59.85 & 20.90 & 46.29 & 1 & 46.29 & 0.11 & 0.735 \\
\hline & Female & 195 & 60.61 & 19.57 & & & & & \\
\hline \multirow{2}{*}{$\begin{array}{l}\text { Ability to use media } \\
\text { and education } \\
\text { resources }\end{array}$} & Male & 132 & 57.39 & 22.85 & 113.99 & 1 & 113.9 & 0.22 & 0.637 \\
\hline & Female & 195 & 58.59 & 22.42 & & & & & \\
\hline
\end{tabular}

Level of significance $<0.005$

Results show that there are no significant differences between genders in terms of classroom management and the use of resources. The mean scores indicate that professionals of both genders are moderately competent in these two aspects.

\section{Working Experience and Teachers' Profesional Competency}

Table 4. ANOVA analysis within groups: Mastery of Professional Competency, by working experience

\begin{tabular}{llllll}
\hline $\begin{array}{l}\text { Professional } \\
\text { competency }\end{array}$ & $\mathrm{r}^{2}$ & $\begin{array}{l}\text { Level of } \\
\text { freedom }\end{array}$ & Mean $^{2}$ & $\mathrm{~F}$ & Sig. \\
\hline $\begin{array}{l}\text { Between } \\
\text { groups }\end{array}$ & 2018.06 & 2 & 1009.0 & 12.03 & 0.000 \\
Whinin groups & 27173.47 & 324 & 83.87 & & \\
Total & 29191.53 & 326 & & & \\
& & & & & \\
\hline
\end{tabular}


From the ANOVA analysis in table 4, it is observed that there is asignificant difference in terms of teachers' professional competency between groups based on working experience.For more details of the difference, you can see in the table below.

Table 5. MANOVA analysis: overall teachers' profesional competency level, by working experience

\begin{tabular}{|c|c|c|c|c|c|}
\hline $\begin{array}{l}\text { (I) } \\
\text { Experience }\end{array}$ & Work & (J) Work Experience & $\begin{array}{l}\text { Mean } \\
\text { Difference } \\
(\mathrm{I}-\mathrm{J})\end{array}$ & Range & Sig. \\
\hline \multirow{2}{*}{$4-9 \quad$ years } & & $10-15$ years & -2.28 & 1.15 & 0.118 \\
\hline & & $16-25$ years & $-6.66\left(^{*}\right)$ & 1.36 & 0.000 \\
\hline \multirow{2}{*}{\multicolumn{2}{|c|}{$10-15$ years }} & 4-9 years & 2.28 & 1.15 & 0.118 \\
\hline & & $16-25$ years & $-4.38(*)$ & 1.33 & 0.003 \\
\hline \multirow{2}{*}{\multicolumn{2}{|c|}{$16-25$ years }} & 4-9 years & $6.66\left(^{*}\right)$ & 1.36 & 0.000 \\
\hline & & $10-15$ years & $4.38(*)$ & 1.33 & 0.003 \\
\hline
\end{tabular}

Level of significance $<0.005$

The table 5 shows that there is significant difference in terms of profssional competency based on teachers' working experience. Teachers with 4 to 9 years of working experience compred to those with 10 to 15 years of expereice show no significanat difference; however, compared to the teachers with 16 to 25 years of working experience there is significant difference.This means that the more experienced teachers, that is, the teachers with over sixteen years of working experience outperformed the less experienced teachers regarding the mastery of professional competency. Therefore, as the past studies highlight (Manullang, 2002; Tillman, 2002) the more experienced the teacher are, the more competent in professional competency they are.

The data shows that the teachers who have 10 to 16 years of experience also show significant diffence compared to the teachers with 16 to 25 years of working experience. The data slso indicates that the teachers who have 16 to 25 years of working experience show significant diference (0.003) compared to the the teachers with 10 to 16 years of working experience.

The result show that the female teachers are more competent and professional compared to the male teachers, which is consistent with the finding of a study by Widyoko (2005). Research by Daniel (2001) found that the competency of the teacher can be improved by focusing on initiative, vision in education, high intellectualthining, technical and cognitive skills. According to Awang, Yousuf \& Ghani (2011), lack of teachers' profesisonal competency can be the consequences of the policy of ministery of education as they do not provide sufficient and comprehensive inservice training for teachers.

\section{Implications and Suggestions}

The study implication is that female teachers are more competent an profesional in comparison with the male teachers. The current study revealed most teachers lack skills in managing classroom effectively. Thus, there are rooms for improvement for teachers especially in terms of classroom management and the utilisation of learning resources. They must be exposed to the best practice of classroom management by visiting other schools either at national or international level. Teachers also need to attend training on the use of various learning resources. It is important for teachers to have creativity in teaching and carrying out their own-initiative to utilise learning resources.

The current study also has an implication for policy makers as data from this study can be used as a guideline in developing short term or long term courses in order to improve educational qualities in Indonesia. As demographic factors play important roles in developing teachers' profesional competency, any policy made by the Ministry of Education Indonesia has to take into account demographic variables. Furthermore, it is suggested that to upgrade the competency level and professional competency among teachers the schools and the ministery of education should provide speciel in-service training for the male teachers.

Due to the importance of working experience in education, the teachers need to reflect on and get feedback from their own performances in the process of teaching and learning in order to be competent and felixable enough to deal with various teaching and learning situation. Accordingly, the school heads should entrust them the tasks 
which demand experience to share with the novice teachers and consequently contrbute to students' academic excellence in the schools.

\section{Conclusion}

The profesional competency of teachers are vital. This is because teachers with high profesional competency are able to help the students not only to get the excellent result in the academics, but also they can teach students how to learn in the appropriate way to be come the holistic students.therefore, the ministery of education and schools should have clear policy and long term program to maintain and upgrade the profesional competency of teachers.

\section{References}

Abdul Razaq Ahmad, Ahamad Rahim, A., \& Seman, A. A. (2013). Active learning through History Subject towards Racial Unity in Malaysia. The Social Science, 8(1), 19-24.

Abdulhak. (2001). Communication of learning: approach to convergence in enhancement the quality of and efektiviti of learning. Bandung: UPI.

Anderson, C. W. (1995). The role of education in the academic disciplines in teacher preparation dalam Woolfolk (Eds), Research perspectives on the graduate preparation of teacher. Englewood Cliffs, NJ: Prentice .

Arifin. (2002). Capita selekta education: Islam and common. Jakarta : Bumi Aksara.

Arikunto. (1990). Management teaching Humanely. Jakarta : Rineka Cipta.

Awang, M. M., Ahmad, A. R., Wahab, J. L. A., \& Mamat, N. (2013). Effective Teaching Strategies To Encourage Learning Behaviour. IOSR Journal, 8(2), 35-40.

Awang, M. M., Jindal-Snape, D., \& Barber, T. (2013). A documentary analysis of the government's circulars on positive behaviour enhancement strategies. Asian Social Science, 9(5), 203-208.

Awang, M. M., Yousuf, M. I., Ghani, S. A. (2011). A study of preferred socio-religious activities by Muslim Youth. European Journal of Social Sciences, 18(4), 596-601.

Bakalis, M. (2003). Direct teaching of paragraph cohesion. Teaching History, 110, 18-26.

Banghart.Trull. (1973). Educational Planning; City Planning; Education; History; Economic Aspects. Macmillan, New York.

Bernardin, H. J., \& Russell, J. E. A. (1993). Human resource management: An experiental approach. McGraw-Hill, Inc.

Biggs, J., \& Tang, C. (2011). Teaching for quality learning at university. McGraw-Hill International.

Blanton et al,(1998). Essentials teaching skills. Boston: Wiley \& Winston.

Cruickshank et al. (2006). Evolution of reflective teaching outcomes. The Journal of Education Research, 75(1), 26-32.

Daborn, J. (1999). What impacts can the development of literacy teaching have on the teaching and learning of history. Retrieved from http:// www.tda.gov.uk/upload/-resources/pdf/c/cottingham-daborn

Daniel, M., \& David, R. (2001). Effective teaching: Evidence and practice. London: Sage Publication Co.

Davies. (2000). The management of learning. New York: MacGraw Hill Co.

De Vito, \& Joseph, A. (1996). Human communication. Terj. Agus Maulana. Komunikasi antar manusia. Jakarta: Professional Books.

Edmond, N., \& Hayler, M. (2013). On either side of the teacher: perspectives on professionalism in education. Journal of Education for Teaching, 39(2), 209-221.

Flippo, R. F. (1999). What do the experts say. San Francisco: Jossey Bass.

Gilley, S. A. (1989). Principles of human resources development. New York : Addison Wesley Publishing Co.

Gillies, R. M., Ashman, A. F., Battistich, V., Watson, M., Terwel, J., Schnackenberg, K. M. H., ... \& Abrami, P. C. (2013). Socialization and learning. Cooperative learning: The social and intellectual outcomes of learning in groups, 1.

Gorman et.al. (1997). Educational renewal : better teacher, better school. San Francisco: Jossey Bass. 
Haydin, T. (2007). Managing pupil behavior: key issues in teaching and learning. Oxon: Routledge.

Hinshaw, K. J., Richter, L. T., \& Kramer, G. A. (2010). Stress, Burnout, and Renewal Activities of Dental Hygiene Education Administrators in Six US Midwestern States. Journal of dental education, 74(3), $235-250$.

Husbands, C, Kitson, A., \& Pendry, A. (2003). Understanding history teaching. Buckingham: Open University Press.

Idris Jauzi. (1990). Education reform in Malaysia: Rationale, philosophy and strategy. Kuala Lumpur: Nurin Enterprise.

Indriyanto. (2001). Academic paper about education personnel. Pusat Penelitian Kebijakan BPPN Depdiknas, Jakarta.

Jamal Ma'mur AHigh Schoolsi. (2009). Seven teacher competence fun and professional. Jogjakarta: PowerBooks.

Langdon, C. A. (1994). The fifth Phi Delta Kappa poll of teachers attitudes towards the public school. Phi Delta International.

Lichtenberger, B. (2013). The Roadmap from Quality Assurance in Programmes and Teaching towards Quality Development as a Strategic Instrument of University Management. Acta Universitatis Danubius. Communicatio, 7(2).

Loughran, J. J., Berry, A. K., \& Mulhall, P. (Eds.). (2012). Understanding and developing science teachers' pedagogical content knowledge (Vol. 12). Springer.

M. Nur Mustafa. (2012). Teacher Perspectives on Work Performance: A Review in High School Risu Province, Pekanbaru, Indonesia. Research Journal of Applied Science, 7(9-2). 458-465.

M. Nur Mustafa. (2013). Factors that Influence Quality Service of Teachers. International Journal Business \& Social Science Research, 3(1), 32-37.

Mannullang, M. (2002). Personnel management. Jakarta: Ghalia Indonesian.

Marks, R. (1991). When should teachers learn Pedagogical content knowledge. Paper presented at Reviews the AERA annual meeting, 1991. California.

Mohd Uzer UHigh Schools. (2000). Teacher professional. Kuala Lumpur: Envoy Publications.

Morrison, D. M., Mohaski, K., \& Cotter, K. (2005). Instructional quality indicators research foundations. Cambridge, MA: Connecticut.

Mulyasa. (2005). Become professional teachers: Create learning creative and fun. Bandung: Teens Rosdakarya.

Mulyasa. (2005). Become professional teachers: Create learning creative and cuddly. Bandung: Teens Rosdakarya.

Norlander, K. A. (2009). My life story A: School of education. Connecticut: University of Connecticut.

Pillay et al. (2005). Well-Being, Burnout and Competence: Implication For Techers. Australian Journal of Teacher Education.

Sardiman. (2004). Learn and learning. Jakarta: Rajawali Press.

Sharifah Alwiah. (1990). Educational Psychology. Kuala Lumpur: Publisher Fajar Bakti Sdn. Bhd.

Shullman, L. S. (1990). Knowledge and teaching: Foundations of Reviews the new reform. Harvard educational review, 57(1), 1-22.

Soedijarto. (1989). Education As a Sarana Reform of Mental In Effort The construction of Bangsa. Indonesis: Balai Pustaka.

Suryosubroto, B. (1997). Some basic aspects of education. Jakarta: Rinneka Cipta.

Sutadiputra. (1985). Various Teachers Problems. Bandung: Angkasa.

Thiessen, D. (2012). Classroom-based teacher. Early professional development for teachers, 317.

Tillman. (2002). Living values: late educational program educators Training Guide. USA: HC.Inc.

Walker, M., Jeffes, J., Hart, R., Lord, P., \& Kinder, K. (2011). Making the links between teachers' professional standards, induction, performance management and continuing professional development RR075. 
Widyoko. (2005). Competence of teacher's teaching IPS SMA Kabupaten Purworejo. Studies Pensyarah Muda. Dirjen Pendidikan Tinggi Indonesian.

\section{Copyrights}

Copyright for this article is retained by the author(s), with first publication rights granted to the journal.

This is an open-access article distributed under the terms and conditions of the Creative Commons Attribution license (http://creativecommons.org/licenses/by/3.0/). 